\title{
Identification and Probiotic Potency Screening of Cellulolytic Bacilli Isolated from Fecal Pellets and Gastrointestinal Tract of Nypha Worm (Namalycastis rhodochorde), West Kalimantan, Indonesia (Identifikasi dan Skrining Potensi Probiotik Basil Selulolitik Diisolasi dari Pelet Tinja dan Saluran Pencernaan Cacing Nipah (Namalycastis rhodochorde), Kalimantan Barat, Indonesia)
}

\author{
TR. Setyawati ${ }^{1}$, AH. Yanti $^{1}$ \& R. Kurniatuhadi ${ }^{2}$ \\ ${ }^{1}$ Zoology Laboratory, Biology Department, Faculty of Mathematics and Natural Science, Tanjungpura \\ University, Pontianak 78241 West Kalimantan, Indonesia \\ ${ }^{2}$ Microbiology Laboratory, Biology Department, Faculty of Mathematics and Natural Science, Tanjungpura \\ University, Pontianak 78241West Kalimantan, Indonesia.
}

Received: July 2021, Accepted: September 2021

\begin{abstract}
The bacterial isolates $\mathrm{NrLtF} 1, \mathrm{NrLtF} 4, \mathrm{NrLtF} 5$, and NrLtG2 isolated from fecal pellets and gastrointestinal tract of nypha worms (Namalycastis rhodochorde) have cellulolytic, proteolytic activity and produce organic acids. The four isolates have the potency to be developed as probiotics in nypha worm cultivation feed. This study aims to determine the probiotics potency and identify the species of NrLtF1, NrLtF4, NrLtF5, and NrLtG2 isolate based on 16srDNA sequence. The probiotic potency was carried out by the acid tolerance assays on distilled water and $0.3 \%$ acid bile media, and the antimicrobial testing against Escherichia coli (MF exp21.12). Bacterial identification was carried out by sequencing of 16sDNA sequence based on GeneBank data. The results showed that the bacterial isolates of NrLtF1, NrLtF4, NrLtF5, and NrLtG2 were able to grow on $0.3 \%$ distilled water and acid bile media. However, only the NrLtF4 and NrLtF5 inhibited E. coli (MF exp21.12) with halo zones $30 \mathrm{~mm}$ and $18 \mathrm{~mm}$, respectively. Blasting results of the 16srDNA sequences showed that the $\mathrm{NrLtF} 1, \mathrm{NrLtF} 4, \mathrm{NrLtF} 5$, and $\mathrm{NrLtG} 2$ were closely related to Bacillus wiedmannii, Brevibacterium sediminis, Bacillus proteolyticus, and Bacillus paramycoides. The nypha worm bacterial isolates have the potency to be developed as probiotics in nypha worm culture.
\end{abstract}

Keywords: Bacillus, Brevibacterium, nypha worm, probiotic

\begin{abstract}
ABSTRAK
NrLtF1, NrLtF4, NrLtF5, dan NrLtG2 yang diisolasi dari pelet tinja dan saluran pencernaan nypha cacing (Namalycastis rhodochorde) memiliki aktivitas selulit, proteolitik dan menghasilkan asam organik. Keempat isolat memiliki potensi untuk dikembangkan sebagai probiotik dalam pakan budidaya nypah cacing. Penelitian ini bertujuan untuk menentukan potensi probiotik dan mengidentifikasi spesies nrltF1, NrLtF4, NrLtF5, dan NrLtG2 isolat berdasarkan urutan 16srDNA. Potensi probiotik dilakukan melalui tes toleransi asam pada air suling dan 0,3\% media empedu asam, dan pengujian antimikroba terhadap Escherichia coli (MF exp21.12). Identifikasi bakteri dilakukan dengan mengurutkan urutan 16sDNA berdasarkan data Gene Bank. Hasil penelitian menunjukkan bahwa isolat bakteri NrLtF1, NrLtF4, NrLtF5, dan NrLtG2 mampu tumbuh pada 0,3\% air suling dan media empedu asam. Namun, hanya NrLtF4 dan NrLtF5 yang menghambat E. coli (MF exp21.12) dengan zona halo masing-masing $30 \mathrm{~mm}$ dan $18 \mathrm{~mm}$. Hasil analisis $16 \mathrm{srDNA}$ menunjukkan bahwa NrLtF1, NrLtF4, NrLtF5, dan NrLtG2 terkait erat dengan Bacillus wiedmannii, Brevibacterium sediminis, Bacillus proteolyticus, dan Bacillus paramycoides. Isolat bakteri pada cacing nipah tersebut memiliki potensi untuk dikembangkan sebagai probiotik dalam kultur cacing nipha.
\end{abstract}

Kata Kunci: Bacillus, Brevibacterium, cacing nipah, probiotik

\section{INTRODUCTION}

Nypa worm (Namalycastis sp.) a worms from the polychaeta class that are spread in Southeast Asia, such as Indonesia, Malaysia, Brunei Darussalam, Philippines, and Thailand. The potential for worms in Indonesia, especially in West Kalimantan, has the potential to be economically developed as raw material for aquaculture feed. Namalycastis rhodochorde is an endemic species in West Kalimantan which has a protein content of more than $58 \%-78 \%$ (Junardi et al. 2010) and has been introduced to aquaculture businesses and coastal communities 
as raw material for fish and shrimp feed (Junardi et al. 2019).

Utilization of nipah worms (Namalycastis rhodochorde) as raw material for high protein aquaculture feed poses ecological challenges. Excessive exploration of nipah worms can cause a decrease in its population in nature. Junardi et al. 2007 have initiated in vitro nipah worm culture. In vitro culture of nipah worms has been successfully carried out until it reaches the juvenile phase. However, culture by invitro has constraints in the speed of growth. Research by Setyawati et al. (2010) showed that the survival rate of nipah worm larvae in phase three stages is less than $20.77 \%$ per month and the growth of the number of body segments to reach 40 segments takes four months. This is very different from the growth of nipah worms in nature which is faster with a length of up to 2 meters in a short time. In addition, larvae and juvenile nipah worms are also very susceptible to disease and parasite attack.

The problem of growth in vitro is the basis for the premise that the growth of nipah worms is very dependent on the availability of nutrients, associated microbes, and the ability to inhibit the growth of parasites and pathogenic microbes. Associated microbial has become a very important study and research in studying the nutritional requirements of several animal associations. The intestinal association of animals such as termites, earthworms, silkworms against cellulolytic microbes is known to help the growth of these animals in the process of providing and absorbing nutrients and as probiotic microbes.

Previous research (Yanti et al. 2017) has succeeded in isolating bacteria suspected of producing organic acids and lactic acid from fecal pellets and gastrointestinal nipah worms. Some isolates are known to have cellulolytic and proteolytic abilities and belong to the group of gram-positive bacilli that can form endospores (Yanti et al. 2020). The research of Khalid et al. (2021) stated that bacteria from the Bacillus group have the potential to be developed as probiotic candidates in animal feed. The results of Zeng et al. (2021) also used Bacillus as a probiotic agent isolated from the gut of broilers and analyzed the immune response and growth of these broilers. The results of the addition of Bacillus probiotics in the study of Zeng et al. have a positive effect on the growth and immune system of broilers.

Most bacteria from the genus Bacillus are harmless to animal cultivation. Bacillus sp. It is known to produce a variety of functional antibiotics such as secondary metabolites, bioinsecticides, enzymes, and lipopeptides, such as iturin, surfactin, fengisin, and bacteriocin (Amin et al. 2020). These important biological and commercial characteristics make them suitable candidates for use as probiotic bacteria, including in the cultivation of nipah worms. The important role of probiotics is based on their antagonistic or antimicrobial activity against enteropathogenic bacteria. This is generally the result of bacteriocin secretion by probiotic cultures or competitive metabolic interactions between probiotics and pathogens.

The ability of these bacteria to break down cellulose from the nipa palm substrate and found in the nipah worm's gastrointestinal tract has the potential to be developed as a probiotic feed for nipah worms. In addition to increasing the digestibility function of nipah worms against cellulose substrates, these bacteria are also expected to provide other functional values, namely inhibiting the development of pathogens for nipah worms. Therefore, this study aims to detect the ability of bacteria as probiotics and to determine the type of species molecularly. This is the basis for further research for the development of probiotic feed for nipah worm cultivation.

\section{MATERIALS AND METHODS}

The catalase test was carried out by dripping $3 \%$ hydrogen peroxide $\left(\mathrm{H}_{2} \mathrm{O}_{2}\right)$ on a clean object glass. The culture is smeared on an object glass that has been dripped with hydrogen peroxide with a dropper. The suspension is mixed slowly using a loop, a positive result is indicated by the formation of air bubbles (Hadioetomo 1990; Cappucino \& Sherman 2005).

The glass slide that had been cleaned with $70 \%$ alcohol was fixed over a Bunsen fire, smeared with bacterial isolate using an ose needle and then the smear was burned three times over a 
Bunsen fire. Furthermore, the isolate was dripped with crystal violet and allowed to stand for 3 minutes, then rinsed with distilled water and dried. Bacterial slides are observed under a microscope.

Erlenmeyer was filled with sterile distilled water and then adjusted until the $\mathrm{pH}$ reached 2.5. Then the distilled water was sterilized by autoclave at $121^{\circ} \mathrm{C}$ for 20 minutes. After sterilization, the distilled water was left to cool and followed by inoculation of 1 ose of bacteria in the distilled water. Then incubated in a shaker bath for 6 hours (Bayane et al. 2010). After 6 hours, the bacterial cell density was measured using a microplate reader.

The $2 \%$ bile acid medium was weighed and diluted using the dilution formula. To make $0.3 \%$ bile acid media, you need $30 \mathrm{~mL}$ of $2 \%$ bile acid in $200 \mathrm{~mL}$ of $0.3 \%$ bile acid media. Then sterilized in an autoclave at $121^{\circ} \mathrm{C}$ for 20 minutes. After cold media, 1 ose of bacteria were inoculated in bile acid broth media and incubated for 6 hours (Bayane et al. 2010).

Antimicrobial test was carried out by testing the sample bacteria with pathogenic bacteria, namely Escherichia coli (MF exp21.12). E. coli bacteria (MF exp21.12) were inoculated in liquid media and incubated for 24 hours. Then it was grown using the swipe method on solid media and also grown samples of bacteria in the middle of the media that had been planted with $E$. coli bacteria (MF exp21.12) and incubated for $3 \times 24$ hours. Probiotic bacteria were characterized by the presence of a clear zone in the media around $E$. coli (MF exp21.12).

Identification of bacteria was conducted by analysis of 16S rRNA sequences. Genomic DNA of each selected bacteria was isolated by using the Ultrac Clean Microbial DNA Isolation Kit according to the manufacturer's instructions. Thus, 16S rRNA gene was amplified by PCR using two general primers $63 \mathrm{~F}$ (5'-CAGGCCTAACACATGCAAGTC-3') and 1867R (5'- GGGCGGWGTGTACAAGGC-3'). Amplification was carried out by PCR (2720 Thermal cycler applied biosystem) in volume of $25 \mu \mathrm{l}$ consisting of $.5 \mu 110 \mathrm{x}$ Kappa taq buffer, $5 \mu \mathrm{l}$ of $1 \mathrm{mM}$ dNTPs, $1 \mu \mathrm{l}$ of 10 $\mathrm{mM}$ each primer, $0.1 \mu \mathrm{l}$ of Kappa taq DNA polymerase, $1 \mu 1$ of DNA templates and $14.4 \mu \mathrm{l}$ of deionized water. First denaturation was at $95^{\circ} \mathrm{C}$ for 3 minutes, 30 cycles with denaturation at $95^{\circ} \mathrm{C}$ for $1 \mathrm{~min}$, annealing at $56^{\circ} \mathrm{C}$ for $45 \mathrm{~s}$, extention at $72^{\circ} \mathrm{C}$ for i min $30 \mathrm{~s}$, and the final extension for 4 min at $72^{\circ} \mathrm{C}$. The products were checked by $1 \%$ agarose gel electrophoresis and stained with $\mathrm{EtBr}$. The amplified product were sequenced. The sequences of $16 \mathrm{~S}$ rRNA genes were used as query to determine the genus and species of its closest prokaryotic relative using BLAST.

\section{RESULTS}

Detection of the characters of four bacteria suspected of producing lactic acid isolated from the gastrointestinal tract of nipah worms (Namalycastis rhodochorde) showed similarities in all the characters analyzed again. The results of the observation of the characters of the four bacteria have a rod shape with consistent endospores, gram-positive groups, can perform $3 \%$ hydrogen peroxide breakdown activity, and are unable to degrade calcium carbonate on Glucose Yeast Peptone (GYP) agar media (Table 1).

The four gram-positive rod-shaped bacteria are known to be able to grow and adapt to probiotic testing which includes a 6-hour acid tolerance test and a $0.3 \%$ bile acid test. The four bacteria were detected spectrophotometrically and grew again when streaked on the surface of GYP agar media.

Table 1. Characterization of cell shape, catalase activity, and degradation of $\mathrm{CaCO} 3$ compounds by cellulolytic bacteria isolated from the gastrointestinal tract of nypa worm.

\begin{tabular}{cccccc}
\hline \multirow{2}{*}{ Isolate code } & \multicolumn{5}{c}{ Characters } \\
\cline { 2 - 5 } & \multirow{2}{*}{ Cell form } & $\begin{array}{c}\text { Gram } \\
\text { staining }\end{array}$ & Sporulation & $\begin{array}{c}\text { Catalase } \\
\text { activity }\end{array}$ & \multirow{2}{*}{ CaCO3 degradation } \\
\hline NrLtF1 & Bacil & Positive & Center & Positive & Negative \\
NrLtF4 & Bacil & Positive & Center & Positive & Negative \\
NrLtF5 & Bacil & Positive & Center & Positive & Negative \\
NrLtG2 & Bacil & Positive & Center & Positive & Negative \\
\hline
\end{tabular}


NrLtG2 bacteria are bacteria with a good tolerance value in the acid tolerance test for 6 hours in a medium without nutrients with a $\mathrm{pH}$ of 2.5 with an OD value: 0.062 , while in the bile acid test $3 \% \mathrm{NrLtF} 1$ bacteria are bacteria with a good tolerance value with an OD value of 0.181. Although the bacteria NrLtG2 and NrLtF1 had the best growth OD values in both acid tolerance tests, they did not have activity to inhibit E. coli using either test methods A or B. NrLtF4 and NrLtF5 bacteria are bacteria that have the potential to be developed as probiotic bacteria. In addition to these two bacteria being able to grow and adapt to the acid resistance test and $0.3 \%$ bile acid test, both bacteria were also able to inhibit the growth of Escherichia coli bacteria. NrLtF 4 bacteria had the largest clear zone diameter compared to the other three isolates, with an inhibitory diameter of up to 30 $\mathrm{mm}$ when using test method B (Table 2).

The measurement of the diameter of the clear zone showed that method A had a lower test effectiveness than test method B. Although the pattern of the two bacteria was the same, namely, NrLtF4 and NrLtF5 were able to inhibit the growth of Escherichia coli, the diameter of the inhibition zone formed was different in the two test methods. The clear zone diameter value of method B is larger than that of method A (Figure 1).

The results of the isolation of the 16sDNA gene showed that the four bacteria had the same DNA band weight of $1300 \mathrm{bp}$. The DNA bands of NrLtF1, NrLtF4, and NrLtF5 were well isolated, which was marked by the formation of clear DNA bands during electrophoresis, while the DNA bands of NrLtG2 isolates were not as bright as the other three isolates.

The results of the BLAST analysis showed that isolates NrLtF1, NrLtF4, NrLtF5, and NrLtG2 were known to have sequences that were similar to Bacillus wiedmannii, Brevibacterium sediminis, Bacillus proteolyticus, Bacillus paramycoides species. The isolates NrLtF1, NrLtF4, NrLtF5, and NrLtG2 were not known to be new indigenous strains in the NCBI database system after the BLASTING process. It is known that the similarity reaches $99 \%$ with the bacterial strain code registered in the database.

\section{DISCUSSION}

The use of probiotics as an alternative to antibiotics has been recommended to be applied in aquaculture to improve the immune system and optimize the digestibility of some organic macromolecules in cultured organisms. Caruffo et al. (2015) recommended the use of indigenous bacteria in the digestive tract to be developed as probiotics because they are more adaptable to the conditions of the gastrointestinal host so that they can easily achieve optimal growth. Soccol et al. (2010) stated that prolonged interaction of native probiotic bacteria with the host led to a

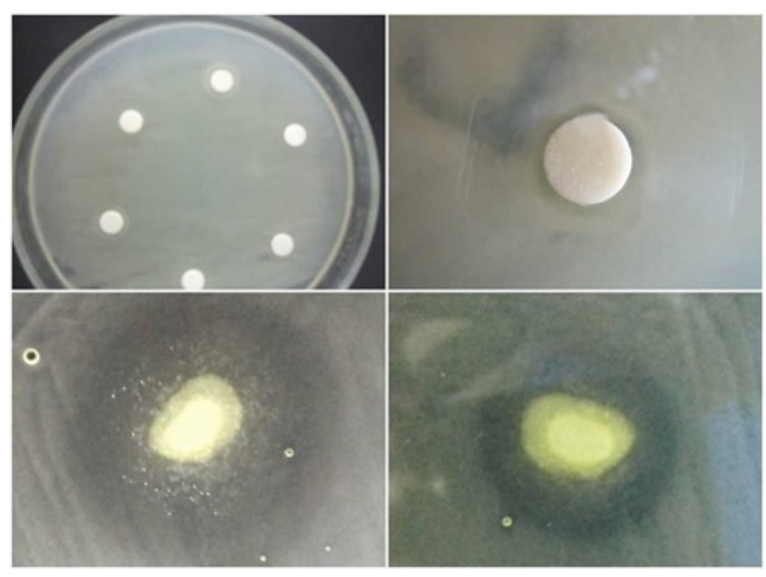

Figure 1. Antimicrobial activity of NrLTF4 and NrLtF5 isolates using the A/Kirby Bauer modified test method (top) and $6 \mathrm{~mm}$ swab test method (bottom).

Table 2. Test results of the probiotic character of cellulolytic bacteria isolated from the gastrointestinal tract of nypa worm.

\begin{tabular}{cccccc}
\hline & \multicolumn{5}{c}{ Probiotic potency test } \\
\cline { 2 - 6 } Isolate code & $\begin{array}{c}\text { Acid tolerance } \\
\text { test }\end{array}$ & $\begin{array}{c}\text { Culture on } \\
\text { GYPA }\end{array}$ & $\begin{array}{c}\text { Acid bile } \\
\mathbf{0 . 3 \%} \text { test }\end{array}$ & $\begin{array}{c}\text { Antibacterial } \\
\text { test A (d; mm) }\end{array}$ & $\begin{array}{c}\text { Antibacterial } \\
\text { test B (d;mm) }\end{array}$ \\
\hline NrLtF1 & moderate & grow & tolerant & 0 & 0 \\
NrLtF4 & moderate & grow & moderate & 7 & 30 \\
NrLtF5 & moderate & grow & moderate & 7 & 18 \\
NrLtG2 & moderate & grow & tolerant & 0 & 0 \\
\hline
\end{tabular}


'balanced relationship' in metabolic activity in both entities. Previous studies have conducted isolation of microbes from the digestive tract of nipah worms. The results of the isolation obtained 58 isolates and 22 isolates of fungi from fecal pellets, coelomic fluid, and the digestive tract of nypha worms ( $N$. rhodochorde). Twenty bacterial isolates are bacteria that are thought to produce organic acids and lactic acid from their metabolic processes (Yanti et al. 2017; 2019; 2020).

Lactobacilli group bacteria are a group of bacteria that are commonly known to be able to produce organic acids in the form of lactic acid from their fermentative catabolism. The results of the repeated detection of four gastrointestinal isolates of nipah worms that were able to grow on MRS Agar media and produce organic acids showed that these bacteria belonged to the nonLactobacilli group (Table 1). Previous studies have reported groups of non-Lactobacilli bacteria as organic acid and lactic acid producing bacteria. Research by Prasirtsak et al. (2013) succeeded in isolating bacteria capable of producing lactic acid from the Paenibacillus, Bacillus, and Brevibacterium groups from soil and leaf litter. The Bacillus group was also

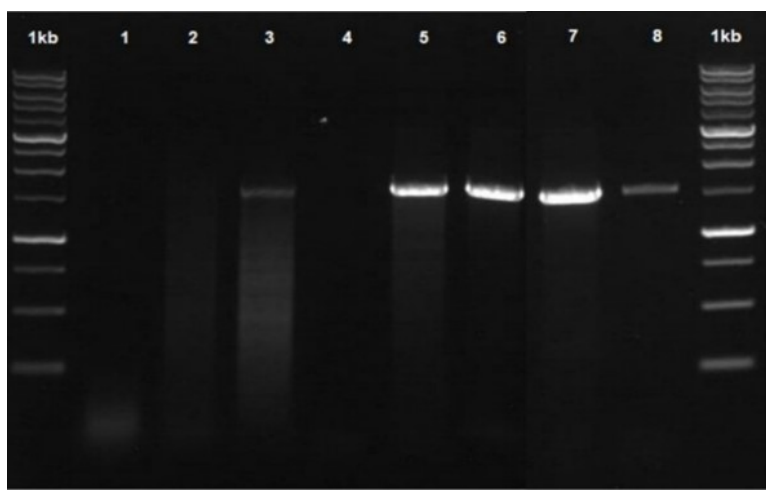

Figure 2. Visualization of DNA bands of $\mathrm{NrLtF} 1$, NrLtF4, NrLtF5, and NrLtG2 bacterial isolates reported by Tanasupawat and Komagata in 2001. Bacteria isolated from MRS Agar medium from the gastrointestinal tract of nipah worms $(N$. rhodochorde) were also identified from the genera Bacillus and Brevibacterium (Table 3). The results of this study strengthen existing research that lactic acid-producing bacteria do not only come from the Lactobacilli group. The Bacilli group, especially the genus Bacillus and Brevibacterium, has the potential to be developed as probiotic bacteria.

The probiotic potential of an isolate can be determined by several tests carried out related to its application to an organism. This is related to the early niche of the ancestral LAB theory proposed by Morelli et al. (2012) that the ancestors of LAB/BAL adapted to soil and gut conditions from plant eaters or plant litter. Tests for resistance to acid and $0.3 \%$ bile acid solution which are characteristics of the digestive tract have been carried out on the three genera of Bacillus and Brevibacterium isolated from nypa worm ( $N$. rhodochorde). The four bacteria were able to grow on acid and bile acid test media (Table 2). These four bacteria have the potential to be developed as probiotics for nipah worm aquaculture feed. Probiotics are currently not only related to Lactobacillus, Leuconostoc, and Bifidobacterium. FAO/WHO has expanded the potential use of various microorganisms such as Gram-positive and Gram-negative bacteria, bacteriophages, microalgae and yeasts. Therefore the definition of probiotics is a live organism, which is administered orally has some obvious health benefits, and is widely used for disease control in culture, especially in developing countries (Irianto \& Austin 2002; Nayak 2010).

The ability to inhibit pathogens is also a consideration in screening potential probiotic bacteria. Bacillus proteolyticus (code NrLtF5) and Brevibacterium sediminis (code NrLtF4)

Table 3. DNA sequence character equations in Gene Bank data.

\begin{tabular}{cclc}
\hline No. & $\begin{array}{c}\text { Kode } \\
\text { Isolat }\end{array}$ & \multicolumn{1}{c}{ Spesies (BLAST NCBI) } & $\begin{array}{c}\text { Similarities } \\
(\%)\end{array}$ \\
\hline 1 & NrLtF1 & Bacillus wiedmannii strain FSL W8-0169 & 99 \\
2 & NrLtF4 & Brevibacterium sediminis strain CGMCC 1.15472 & 99 \\
3 & NrLtF5 & Bacillus proteolyticus strain MCCC 1A00365 & 99 \\
4 & NrLtG2 & Bacillus paramycoides strain MCCC 1A04098 & 99 \\
\hline
\end{tabular}


are known to have the ability to inhibit $E$. coli. This ability provides added value for the two bacteria from the gastrointestinal tract of the nipah worm, which has the potential to be developed as probiotics. Brevibaterium isolated from the gastrointestinal tract of nipah worms showed the ability to inhibit $E$. coli to form an inhibition zone or halo of $30 \mathrm{~mm}$. This antibiosis potential was higher than the ability of Brevibacterium isolated by Motta \& Brandelli (2002) against Listeria monocytogenes which was only able to produce a $10 \mathrm{~mm}$ halo zone.

Antibiotic ability of Brevibacterium and Bacillus has been known through the process of forming bacteriocin and linocin M-18 compounds which are also able to inhibit the growth of pathogens such as Listeria monocytogenes and S. typhi (Valdes-Stauber \& Scherer 1994; Kuta et al. 2009). Research by Larsen et al (2013) showed that bacteria from Bacillus spp. also developed as a probiotic with antibiotic function for pig feed. Cutting (2011) stated that Bacillus can be used as a probiotic supplement in animal feed. Their thermal stability and ability to withstand gastric acid make them potential as animal feed additives. Although Bacillus is often considered a soil organism, this conception is misplaced and Bacillus should be considered as an intestinal commensal, this is due to some animals that are detritivores in soil, including the nipah worm. Denkova et al. (2017) stated that according to the definition of probiotics by WHO and probiotic researchers that potential probiotic candidate bacteria are bacteria that are resistant to acidity tests and are able to inhibit several pathogenic organisms including aquaculture organisms. This indicates that Bacillus proteolyticus (code NrLtF5) and Brevibacterium sediminis (code NrLtF4) can be selected as probiotic candidates and need to be tested invivo through feed formulations for aquaculture organisms.

\section{CONCLUSION}

NrLtF1, NrLtF4, NrLtF5, and NrLtG2 isolates were known to have sequences that were similar to Bacillus wiedmannii, Brevibacterium sediminis, Bacillus proteolyticus, and
Bacillus paramycoides species. The four bacteria have characters that characterize the character of potential probiotic candidates, namely being able to grow on acid test media and $0.3 \%$ bile media. Two bacterial isolates were known to be able to inhibit the E. coli test pathogens with inhibition zone diameters of 18 and $30 \mathrm{~mm}$, respectively. Potential probiotic bacteria derived from nipah worms can be developed through prebiotic mapping to obtain optimal growth. Therefore, further research is needed on mapping and the effect of prebiotic compounds on the growth of potential probiotic bacteria from nipah worms ( $N$. rhodochorde). This will support the formulation of nipah worm animal feed which involves probiotic bacteria as one of its components.

\section{ACKNOWLEGMENTS}

We would like to thank the Indonesian Research Institute (LIPI) for assisting in DNA sequence analysis and The Cacing Nipah Research Team for assisting in the sampling process in the field, so that this research can be completed properly

\section{AUTHOR CONTRIBUTIONS}

TRS, as main contributor, AHY, and RK contributed to data collection, data analysis, and of this article.

\section{REFERENCES}

Amin, FAZ., S. Sabri, M. Ismail, KW. Chan, N. Ismail, NM. Esa, MAM. Lila, N. Zawawi. 2019. Probiotic Properties of Bacillus Strains Isolated from Stingless Bee (Heterotrigonaitama) Honey Collected across Malaysia. International Journal Environmental Research Public Health. 17(1):278. Published 2019 Dec 31. doi:10.3390/ ijerph17010278.

Caruffo, M., N. Navarrete, O. Salgado. A. Diaz, P. Lopez, K. Garcia, CG. Feijoo \& P. Navarette. 2015. Potential probiotic yeasts isolated from the fish gut protect zebrafish (Danio rerio) from a Vibrio anguillarum 
challenge. Front Microbiol. 6:1093. doi:10.33 89/ fmicb.2015.01093.

Cutting SM. 2011. Bacillus probiotics. Food Microbiol. 28 (2):214-20. doi: 10.1016/ j.fm.2010.03.007. Epub 2010 Mar 24.

Denkova, R., B. Goranov, D. Teneva, Z. Denkova, \& G. Kostov 2017. Antimicrobial activity of probiotic microorganisms: mechanisms of interaction and methods of examination.

Irianto, A. \& B. Austin. 2002. "Use of probiotics to control furunculosis in rainbow trout, Oncorhynchus mykiss (Walbaum)." Journal of Fish Diseases 25 (6): 333-342.

Khalid, F., A. Khalid, Y. Fu, Q. Hu, Y. Zheng S. Khan, \& Z. Wang. 2021. Potential of Bacillus velezensis as a probiotic in animal feed: a review. Journal Microbiology. 59 (7): 627-633. doi: 10.1007/s12275-021-1161-1.

Kuta, FA., L. Nimzing, \& P. Orka'a. 2009. Screening of Bacillus species with potentials of antibiotics production. Applied Medical Informatics. 24 (1-2): 42-46.

Larsen, N., L. Thorsen, EN. Kpikpi, B. StuerLauridsen, MD. Cantor, B. Nielsen, E. Brockmann, PM. Derkx, \& L. Jespersen. 2014. Characterization of Bacillus spp. strains for use as probiotic additives in pig feed. Applied Microbiology and Biotechnology. 98 (3):1105-18. doi: 10.1007/ s00253-0131.
Mingmongkolchai, S. \& W. Panbangred. 2018. Bacillus probiotics: an alternative to antibiotics for livestock production, Journal Applied Microbiology 124(6):1334-1346.

Motta, AS., \& A. Brandelli. 2002. Characterization of an antibacterial peptide produced by Brevibacterium linens. Journal Applied Microbiology. 92(1): 63-70. doi: 10.1046/ j.1365-2672.2002.01490.x.PMID: 11849329.

Nayak, SK. 2010. Probiotics and immunity: a fish perspective. Fish and Shellfish Immunology. 29 (1): 2-14.

Soccol, C., L. Vandenberghe, MR. Spier, AB. Medeiros, CT. Yamaguishi, J. Lindner, A. Pandey \& V. Thomaz-Soccol. 2010. The potential of probiotics: a review. Food Technology and Biotechnology .48: 413-434.

Valdés-Stauber, N., \& S. Scherer. 1994. Isolation and characterization of Linocin M18, a bacteriocin produced by Brevibacterium linens. Applied Environmental and Microbiology. 60(10):3809-14. doi:10.1128/aem. 60.10.3809-3814.1994.PMID:7986050; PMCID: PMC201890.

Zeng, X, Q. Li, C. Yang, Y. Yu, Z. Fu, H. Wang, X. Fan, M. Yue, \& Y. Xu. 2021. Effects of Clostridium butyricum- and Bacillus spp. -Based Potential Probiotics on the Growth Performance, Intestinal Morphology, Immune Responses, and Caecal Microbiota in Broilers. Antibiotics (Basel). 10(6): 624. doi: 10.3390/antibiotics 10060624 . 
